\title{
Penyuluhan dan Pelatihan Pengolahan Limbah Plastik Menjadi Bahan Bakar Minyak Untuk Mengatasi Sampah Plastik Di Kota Bontang
}

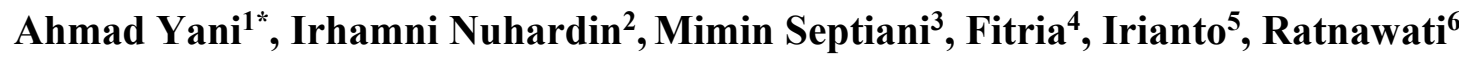 \\ ${ }^{1,5,6}$ Program Studi Teknik Mesin Sekolah Tinggi Teknologi Industri Bontang, Indonesia \\ 2,3,4 Program Studi Teknik Kimia Sekolah Tinggi Teknologi Industri Bontang, Indonesia \\ Jl. Brigjend Katamso No. 40 Bontang - Kalimantan Timur \\ "yanibima@gmail.com
}

\begin{abstract}
Plastic waste is a type of inorganic waste that is difficult to decompose in soil and water. Plastic waste is usually only piled up and disposed of, causing various kinds of negative impacts. One of the efforts to tackle plastic waste in Bontang City is to create a tool that can convert plastic waste into fuel oil. The purpose of this community service is to provide an understanding to the community (students) regarding the dangers of plastic waste to the environment and to provide knowledge to the public about how to process plastic waste into fuel oil using practical and inexpensive pyrolysis technology. The method of implementing this community service activity is in the form of counseling and training. The results of this community service received a very good response from students and teachers. This response can be seen from the enthusiasm of the participants when carrying out the practice of processing plastic waste into fuel oil. The conclusion of this community service has a very positive impact on the processing of plastic waste into fuel oil and changes the habits of the Bontang people, which initially only disposed of plastic waste, then utilized it so that it had economic value.
\end{abstract}

Keywords: Plastic waste, fuel oil

\begin{abstract}
Abstrak
Sampah plastik merupakan jenis limbah an organik yang sukar terurai dalam tanah maupun air. limbah plastik biasanya hanya ditimbun dan dibuang sehingga menimbulkan berbagai macam dampak negatif. Salah satu upaya untuk menanggulangi limbah plastik di Kota Bontang adalah menciptakan alat yang dapat merubah limbah plastik menjadi bahan bakar minyak. Tujuan pengabdian masyarakat ini untuk memberikan pemahaman kepada masyarakat (siswa) terkait bahaya limbah plastik bagi lingkungan dan memberikan pengetahuan kepada masyarakat tentang cara pengolahan limbah plastik menjadi bahan bakar minyak dengan menggunakan teknologi pirolisis yang praktis dan murah. Metode pelaksanaan kegiatan pengabdian masyarakat ini berupa penyuluhan dan pelatihan. Hasil pengabdian masyarakat ini mendapat respon yang sangat baik dari siswa dan guru. Respon tersebut terlihat dari semangat para peserta saat melaksanakan praktek pengolahan limbah plastik menjadi bahan bakar minyak. Kesimpulan pengabdian masyarakat ini memberikan dampak yang sangat positif terhadap pengolahan limbah plastik menjadi bahan bakar minyak dan merubah kebiasaan masyarakat Bontang yang semula limbah plastik hanya dibuang, kemudian dimanfaatan sehingga bernilai ekomanis.

Keywords: Limbah plastik, bahan bakar minyak
\end{abstract}

\section{PENDAHULUAN}

Sampah merupakan salah satu permasalahan yang cukup mendasar di kabupaten dan Kota di Indonesia (Stiyana ddk, 2019). Salah satunya di Kota Bontang. Ancaman sampah di Kota Bontang menjadi masalah serius dikarenakan setiap harinya petugas kebersihan mengangkut 90 ton sampah untuk dibawa ke Tempat Pembuangan Akhir (TPA) dan produksi sampah warga bontang mencapai 2.700 ton perbulan (Dinas Lingkungan Hidup, 2019). disamping itu sampah plastik memberi sumbangsih $90 \%$ sampah yang ada di lautan, menyebabkan kerusakan ekosistem pantai sehingga terjadi degradasi ekosistem wilayah pesisir (Vatria,2013). Untuk mengantisipasi hal tersebut, Walikota Bontang Neni Moerniaeni menyiapkan produk hukum mengatur penggunaan sampah plastik yaitu melalui peraturan walikota Bontang Nomor 30 Tahun 2018 tentang pengurangan penggunaan sampah plastik sekali pakai. 
Sampah plastik merupakan jenis limbah anorganik yang sukar terurai dalam tanah dan membutuhkan waktu sebanyak 50-80 juta tahun untuk terurai (Ariyanto, 2017). Pengelolaan limbah plastik dilingkungan rumah warga oleh masyarakat Bontang biasanya hanya ditimbun atau dibuang sehingga menimbulkan berbagai macam dampak negatif, karena tidak selamanya menimbun limbah akan menyelesaikan masalah. Menurut data Dinas Lingkungan Hidup Kota Bontang yang penulis dapatkan bahwa rata-rata jumlah sampah plastik sebesar $22.690 \mathrm{~kg} /$ bulan atau setara $271.865 \mathrm{~kg} /$ Tahun. Pembuangan sampah di Tempat Pembuangan Akhir (TPA) Bontang tidak cukup maksimal sebagai solusi pengolahan sampah plastik ini, mengingat proses penumpukan sampah yang semakin banyak dan proses degradasi yang cukup lama, sehingga perlu adanya inovasi pengolahan sampah plastik dengan teknologi. Teknologi pirolisis merupakan salah satu alternative penyelesaian masalah sampah an organic yang sulit didaur ulang seperti label botol air minum kemasan (Mandala ddk, 2016), bungkus plastic berlapis alumunium (Pratiwi, 2017), tas kresek (Liestiono ddk, 2016), Styrofoam (Salma \& Maryudi, 2018).

Salah satu upaya yang penulis lakukan untuk menanggulangi sampah plastik di Kota Bontang adalah menciptakan alat yang dapat merubah sampah plastik menjadi bahan bakar minyak yang dapat menjadi solusi untuk mengatasi permasalahan sampah plastik yang ada di Kota Bontang. Tujuan dari pelaksanan pengabdian masyarakat ini untuk memberikan pemahaman kepada masyarakat (siswa) terkait bahaya sampah plastik bagi lingkungan dan memberikan pengetahuan kepada siswa tentang cara pengolahan sampah plastik menjadi bahan bakar minyak dengan menggunakan teknologi pirolisis yang praktis dan biayanya murah.

\section{METODE PELAKSANAAN}

Metode pelaksanaan kegiatan pengabdian masyarakat ini berupa penyuluhan dan pelatihan kepada siswa. Sedangkan tempat pelaksaan pengabdian masyarakat ini bertempat di SMK Rigomasi yang beralamat di jalan Ahmad Yani No. 1 Kelurahan Api-api Kec. Bontang Uatara Kota Bontang. Jumlah peserta yang mengikuti kegitan ini sebanyak 50 orang dengan latar belakang siswa SMK kelas XII beserta guru wali kelasnya dan guru mata pelajaran Prakarya SMK Rigomasi Bontang.

\section{Materi Penyuluhan}

1. Sosialisasi peraturan walikota Bontang Nomor 30 Tahun 2018 tentang pengurangan penggunaan sampah plastik sekali pakai.

2. Dampak limbah plastik bagi lingkungan

3. Manfaat pengolahan limbah plastik bagi lingkungan dan kesehatan

4. Cara pengolahan limbah plasti menjadi bahan bakar minyak (bensin)

\section{Prosedur dan metode Pelatihan}

Setelah dilakukan penyuluhan, maka selanjutnya melakukan pelatihan atau uji coba pengolahan limbah plastik menjadi bahan bakar minyak kepada siswa melalui beberapa tahap proses seperti ditunjukkan pada gambar 1 . 


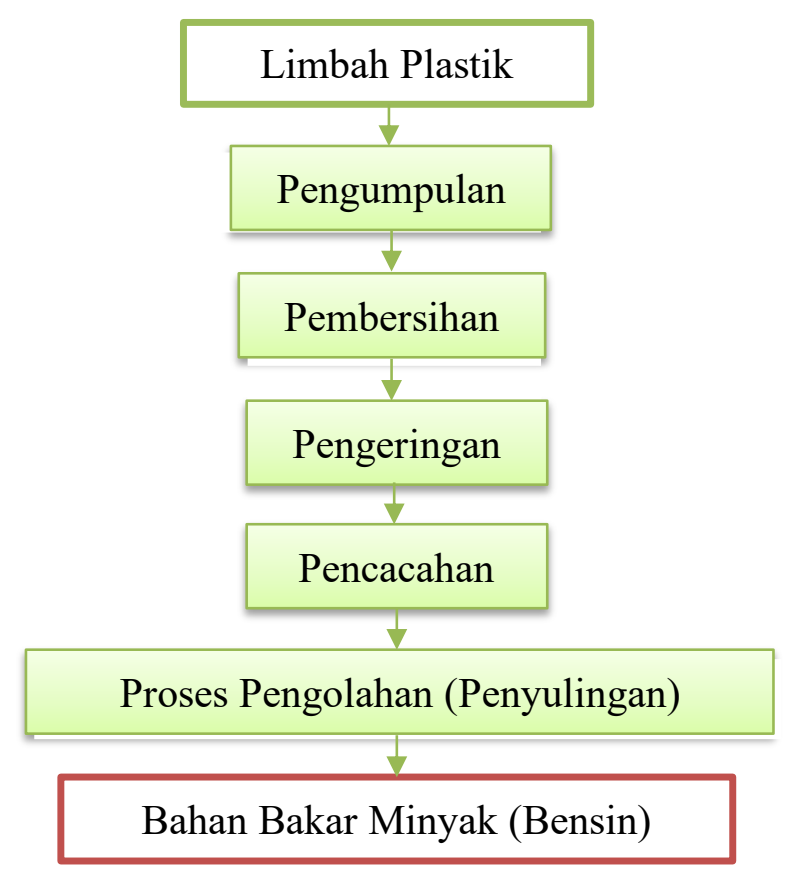

Gambar 1. Diagram alir proses pengolahan limbah plastik menjadi BBM

Alat pengolahan limbah plastik yang penulis buat ini cukup sederhana sehingga mudah dioperasikan oleh masyarakat dan proses pembuatan alat ini sebagaian besar menggunakan barang bekas yang didapatkan dari tempat penampungan barang bekas di Kota Bontang. Pada tabung reaktor yang berukuran 15 liter di dipasang alat ukur temperature gauge untuk mengetahui suhu didalam reaktor, pada tabung reaktor terdapat cup reaktor sebagai tempat memasukan limbah plastik untuk diolah menjadi bahan bakar minyak. Pada tabung reaktor terdapat katup untuk tempat mengalirnya asap cair melalui tube kondensor dan tube kondensor tersebut didinginkan dengan air yang ada pada toples untuk merubah fase asap cair menjadi bahan bakar minyak. alat ini cukup praktis, ekonomis, portable dan mudah dioperasikan oleh masyarakat. Bentuk alat pengolahan limbah plastic menjadi bahan bakar minyak (bensin) yang digunakan untuk pelatihan dlm pengabdian masyarakat ini seperti ditunjukkan pada gambar 2 .

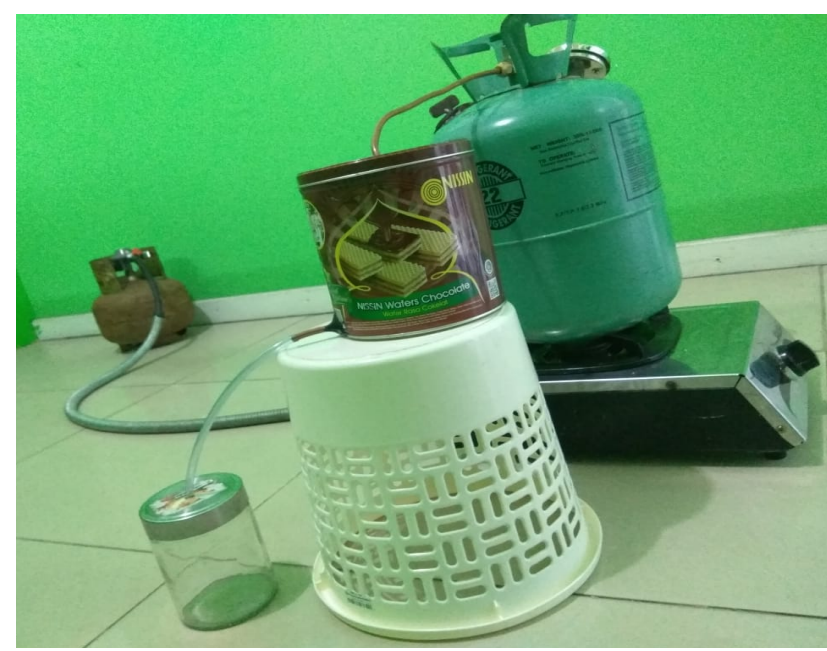

Gambar 2. Rangkaian alat pengolahan limbah plastik menjadi bahan bakar minyak (bensin)

(Sumber: Dokumentasi Penelitian Penulis) 


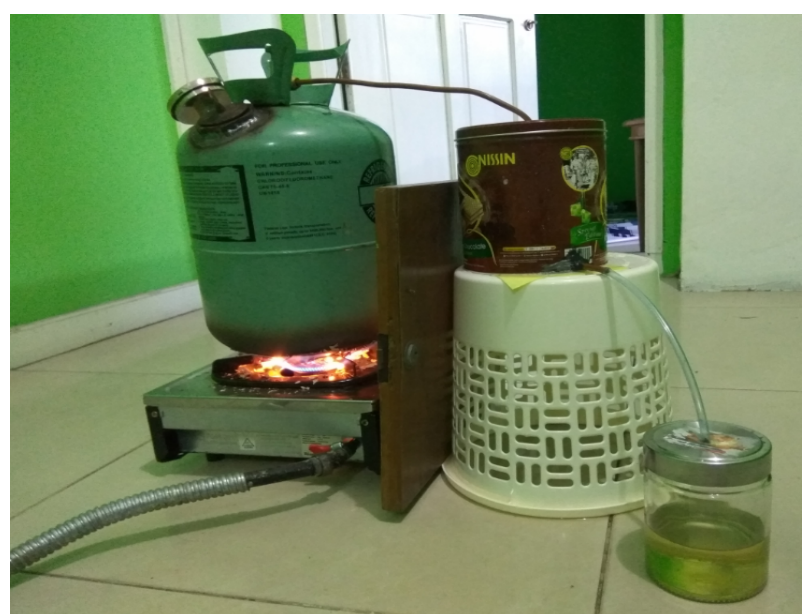

Gambar 3. Hasil pengolahan limbah plastik menjadi bahan bakar minyak (bensin)

(Sumber: Dokumentasi Penelitian Penulis)

\section{HASIL DAN PEMBAHASAN}

\section{Hasil Pengabdian Masyarakat}

Hasil pengabdian masyarakat ini merupakan uraian data dokumentasi kegiatan berupa gambar yang diperoleh dari pelaksanaan pengabdian masyarakat di SMK Rigomasi Bontang seperti ditujukkan pada gambar 4 dan 5 .
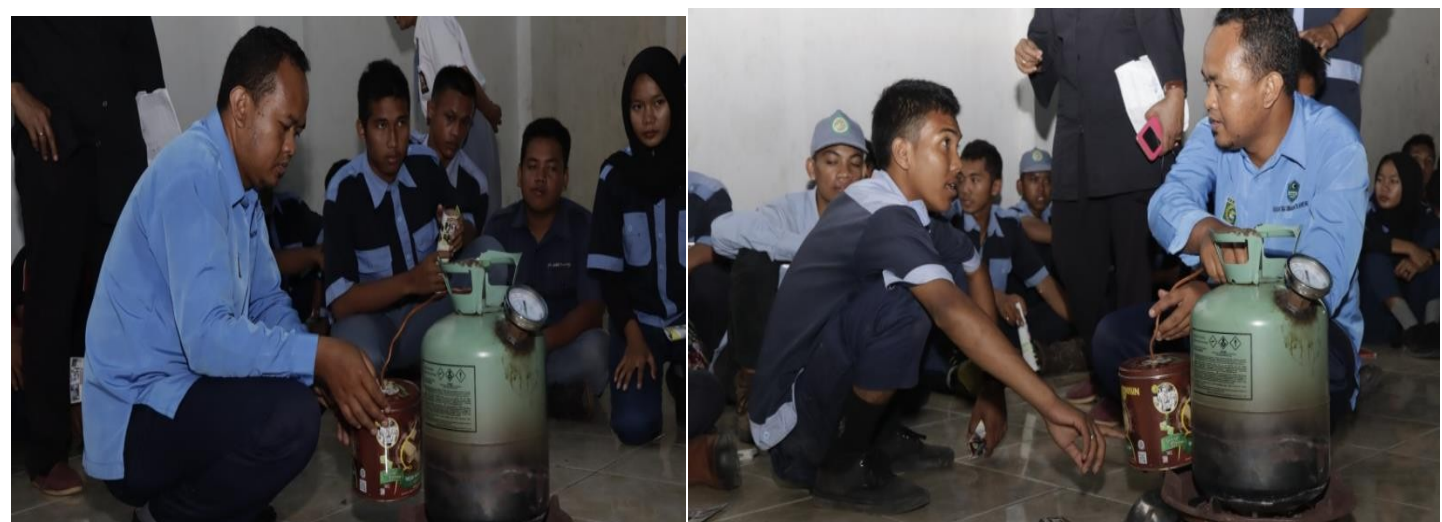

Gambar 4. Demostrasi alat pengolahan sampah plastik sambil diskusi dengan peserta

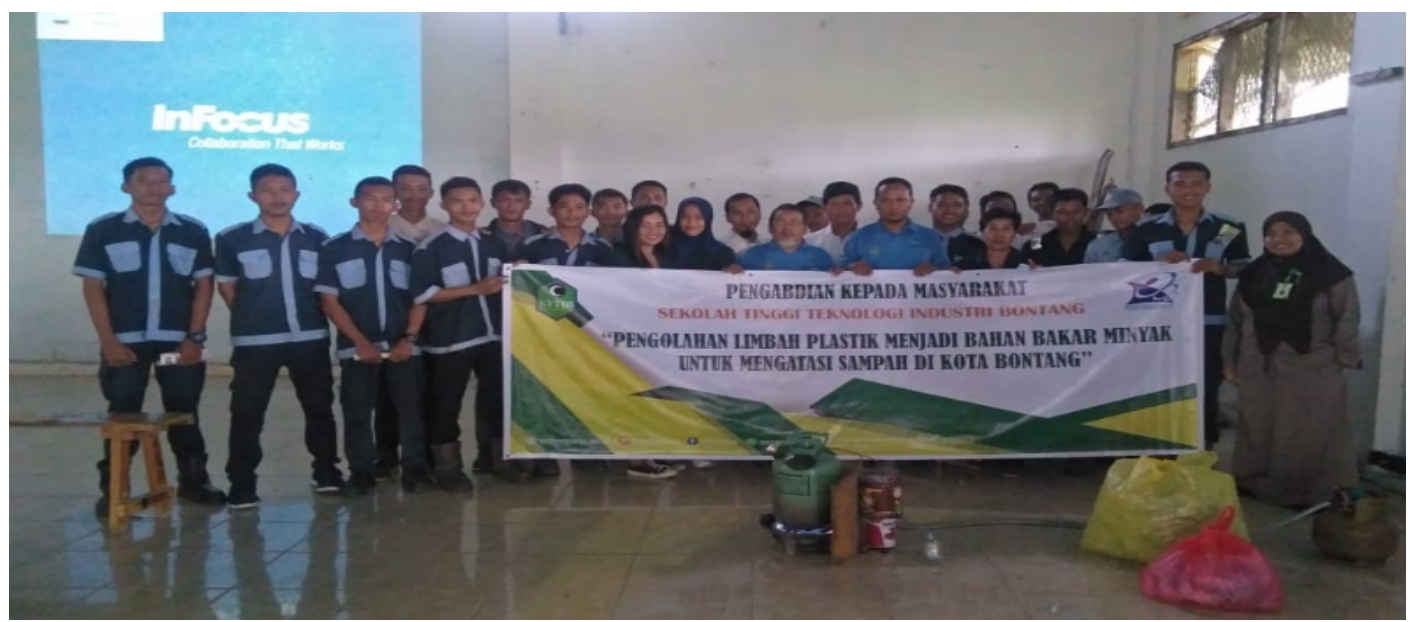

Gambar 5. Foto bersama dengan peserta dan team pengabdian masyarakat 


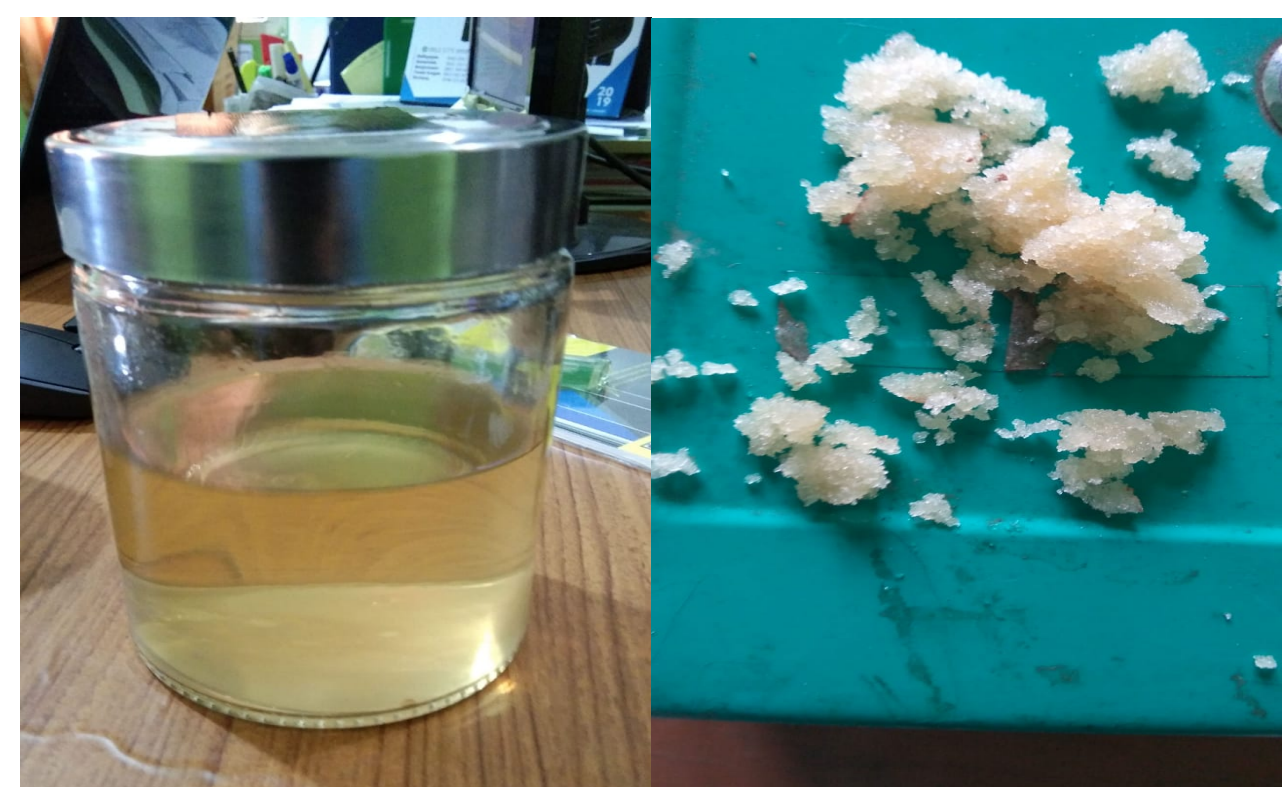

Gambar 6. Hasil pengolahan sampah plastik berupa bahan bakar minyak dan limbah padatnya

\section{Pembahasan}

Kegiatan pengabdian masyarakat ini mendapat respon yang sangat baik dari siswa dan guru SMK Rigomasi. Respon tersebut terlihat dari semangat para peserta pada saat melaksanakan praktek pengolahan limbah plastic menjadi bahan bakar minyak serta pada sesi diskusi para peserta memberikan pertanyaan-pertanyaan terkait pengolahan limbah plastik menjadi bahan bakar minyak dan penggunakan limbah hasil proses tersebut. Penyuluhan dan pelatihan ini disampaikan dengan harapan para peserta dapat menerapkan pengolahan sampah plastic dalam dilingkungan sekolah maupun lingkungan masyarakat sehingga peraturan walikota Bontang Nomor 30 Tahun 2018 tentang pengurangan penggunaan sampah plastik sekali pakai dapat diterapkan dengan mudah. Disamping itu penggunaan plastik yang berlebihan mengakibatkan jumlah timbulan limbah plastik yang sangat besar. Dalam kondisi seperti itu dapat menimbulkan dampak negatif bagi lingkungan, sebagai berikut:

1. Tercemarnya tanah, air tanah dan makhluk bawah tanah. Racun-racun dari partikel plastik yang masuk ke dalam tanah akan membunuh hewan-hewan pengurai di dalam tanah seperti cacing. Kantong plastik akan mengganggu jalur air yang teresap ke dalam tanah. Menurunkan kesuburan tanah karena plastik juga menghalangi sirkulasi udara di dalam tanah dan ruang gerak makhluk bawah tanah yang mampu meyuburkan tanah.

2. Pembuangan limbah plastik sembarangan di sungai-sungai akan mengakibatkan pendangkalan dan penyumbatan aliran air sungai.

3. Limbah jenis kantong plastik akan mengganggu jalur air yang meresap ke dalam tanah.

4. Jika dibakar, limbah plastik akan menghasilkan asap beracun yang berbahaya bagi kesehatan yaitu jika proses pembakaranya tidak sempurna, plastik akan mengurai di udara sebagai dioksin. Senyawa ini sangat berbahaya bila terhirup manusia. Dampaknya antara lain memicu penyakit kanker, hepatitis, pembengkakan hati, gangguan sistem saraf dan memicu depresi. 
Sedangkan manfaat pengolahan limbah plastik bagi lingkungan dan kesehatan yaitu untuk mengurangi jumlah limbah plastik yaitu dengan cara mengolah limbah plastik menjadi bahan bakar minyak. Adapun manfaat dari pengolahan limbah plastik sebagai berikut:

1. Mengurangi pencemaran

Pencemaran tanah dan air laut dipantai sangat didominasi oleh limbah plastik. Hal ini disebabkan konsumsi plastik tidak terbatas, sedangkan kesadaran akan dampak yang ditimbulkan belum dipahami. Lapisan tanah yang terkontaminasi dengan limbah plastik menyebabkan rusaknya lapisan humus. Sedangkan air laut yang terkontaminasi dengan plastik, akan menyebabkan rusaknya ekosistem dilaut sehingga terjadi degradasi ekosistem wilayah pesisir. Jika pengolahan limbah plastik yang terdapat di lingkungan sekitar kita menjadi minyak, bisa sedikit membantu mengurangi dampak tersebut.

2. Lingkungan Asri

Suatu lingkungan dapat dikatakan asri apabila memenuhi bersih, sehat dan nyaman. Lingkungan asri dapat tercipta apabila lingkungan tersebut bersih dari sampah plastik yang berserakan. Jika lingkungan tersebut bersih, maka akan tercipta lingkungan yang sehat. Untuk menciptakan lingkungan yang asri memerlukan beberapa tindakan atau langkah yang dapat ditempuh diantaranya mengolah sampah menjadi barang yang bernilai ekonomis.

3. Penghematan lahan Tempat Pembuangan Akhir (TPA)

Sampah plastik merupakan salah satu limbah yang berpengaruh cukup besar terhadap tempat pembuangan akhir (TPA). Pengelolaan sampah plastik yang hanya cukup ditimbun atau dibuang akan menimbulkan berbagai macam dampak negatif, karena tidak selamanya menimbun lmbah plastik akan menyelesaikan masalah.

\section{KESIMPULAN}

Pada penyuluhan dan pelatihan pembuatan bahan bakar minyak (bensin) dari sampah plastik maka diperoleh kesimpulan bahwa dampak dari pengabdian masyarakat ini antara lain:

1. Pada dasarnya pengabdian masyarakat ini memberikan dampak yang sangat positif terhadap pengolahan limbah plastik, dimana limbah plastik dapat menyebabkan pencemaran lingkungan, kemudian diolah menjadi bahan bakar minyak.

2. Memperkenalkan cara membuat teknologi tepat guna untuk menanggulangi limbah plastik di Kota Bontang sehingga dapat merubah limbah plastik menjadi bahan bakar minyak yang dapat meningkatkan pendapatan masyarakat Kota Bontang karena dari limbah plastik dapat mengasilkan bahan bakar minyak yang bernilai ekonomis.

3. Merubah kebiasaan masyarakat Bontang dalam pengelolaan limbah plastik yang semula hanya dibuang, kemudian dapat dimanfaatan bernilai ekomanis dengan cara pengolahan untuk dijadikan bahan bakar minyak.

4. Setelah adanya pengabdian masyarakat ini limbah plastik yang ada di lingkungan sekolah SMK Rigomasi maupun dimasyarakat dapat diolah sendiri sehingga mendapatkan keuntungan dari hasil pengolahan limbah menjadi minyak nilai ekonomis.

5. Setelah adanya pengabdian masyarakat ini dapat mengurangi limbah plastic yang ada di sekolah SMK Rigomasi karena alat yang sederhana ini sangat efektif untuk diaplikasikan di sekolah sebagai bentuk aplikasi teknologi pengolahan sampah plasti yang ada di sekolah 


\section{DAFTAR PUSTAKA}

Anonimous. Dinas Linkungan Hidup. Kota Bontang. 2019

Liestiono R.P., Cahyono M.S., Widura W.W., Prasetya, A., \& Syamsiro, M., Karakteristik Minyak Dan Gas Hasil Proses Dekomposisi Termal Plastik Jenis Low Density Polythylene (LDPE), Jurnal OFFSHORE, Vol. 1, No. 2, Desember 2017, hal 1-9.

Mandala, W.W., Cahyono, M.S., Ma'afif, S., Sukarjo, H.B., \& Wardoyo, 2016, Pengaruh Suhu Terhadap Rendemen Dan Nilai Kalor Minyak Hasil Pirolisis Sampah Plastik, Jurnal Mekanika Dan Sistem Termal. Vol. 1, No. 2, Agustus 2016, hal 49-52.

Moernaini, N. Peraturan Wali Kota Bontang Nomor 30. Tentang Pengurangan Penggunaan Sampah Plastik Sekali Pakai Kota Bontang. 2018.

Pratiwi, D., 2017., Proses Pirolisis Dan Karakteristik Produk Pirolisis Sampah Plastik Polyethylene (PE) dan Polypropylene (PP) Berlapis Aluminium Dengan Katalis Zeolit Alam Gunung Kidul, Tesis Magister Teknik Sistem, Universitas Gajah Mada.

Salma, S \& Maryudi., Proses Pirolisis Limbah Styrifoam Menggunakan Katalis Silika Alumina, Jurnal Rekayasa Kimia dan Lingkungan Vo. 13, No.1, Juni 2018, hal 1-7.

Styana, Ucuk. I.F., Hindarti, F., Aridito, M.N., \& Cahyono, M.S., Penerapan Teknilogi Pengolahan Sampah Plastic Menjadi Bahan Bakar Minyak Untuk Mengatasi Masalah Sampah di Kota Bandung. Jurnal Pengabdian MAsyarakat bidang teknologi, KACANEGARA. Vol. 2 No. 1 2019. Hal 1-6.

Vatria, B., Berbagai Kegiatan Manusia yang Daoat Menyebabkan Terjadinya Degradasi Ekosistem Pantai Serta Dampak yang ditimbulkannya. Kumpulan e-Journal Belian 9 (1): 47-54. 2018.

\section{Profil Penulis:}

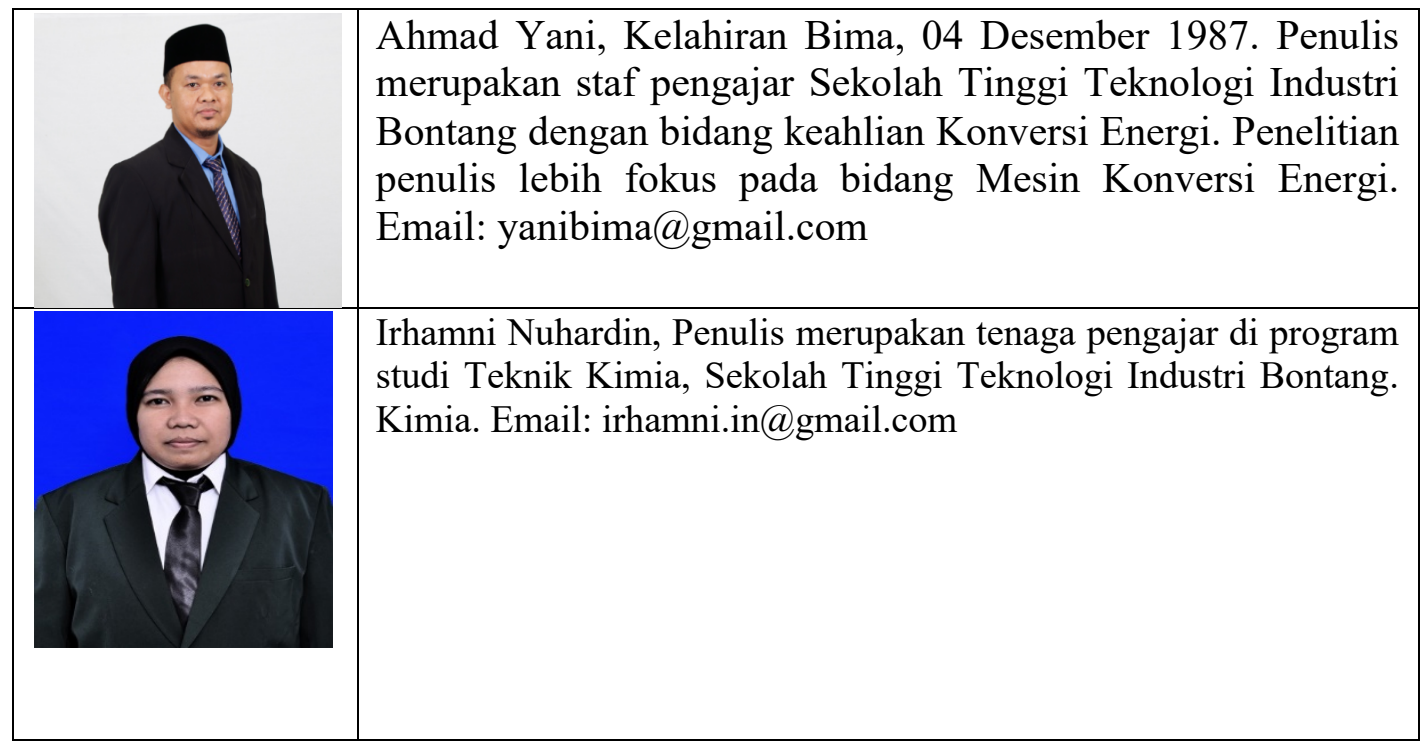




Mimin Septiani, Penulis merupakan tenaga pengajar di program
studi Teknik Kimia, Sekolah Tinggi Teknologi Industri Bontang.
Email: hallomimi@technologist.com

